\title{
Management in the tourism industry as the flagship of the national and regional development of the service sector
}

\author{
Diclovar Kodirzoda ${ }^{1}$, Alla Matveeva ${ }^{2, *}$, Ekaterina Yalunina ${ }^{2}$, and Roman Krasnov ${ }^{2}$ \\ ${ }^{1}$ Ministry of Education and Science, Dushanbe, Nisora Muhammad Street, 13A, Tajikistan \\ ${ }^{2}$ Ural State University of Economics, 8 Marta/NarodnoyVoli St. 62/45, 620144 Ekaterinburg, Russia
}

\begin{abstract}
The article describes the versatility of the service sector in the tourism industry. It is argued that a clear definition and even an idea of management in the tourism industry as the flagship of the national and regional development of the service sector has not yet fully developed in the scientific community. The complexity, significance and relative novelty of the service sector in the tourism industry, as well as the lack of fundamental work in this area, have led to the emergence and use of many terms that define its essence. Over the past ten years, the regional administration in Russia has been undergoing a clear transformation and a new approach to strategy development is being formed.As the Russian tourism industry's market for services represents an innovative management and socio-economic platform with a regional character, new management and development technologies should be more actively developed and implemented in the most resource-appropriate territories. The problems of strategic development of the service sector and management in the tourism industry are considered on the example of the servirization of the Sverdlovsk region.
\end{abstract}

\section{Introduction}

Progressive service development contains the following components: theoretical, industry (technological), market, strategic and managerial. The versatility of the service sector can only be studied by identifying the state and development of these components, both individually and in the industry-wide.

The flagship of national and regional development in the service sector is management in the tourism industry. There is a direct link between the development of management in the tourism industry and the information, economic, technical, cultural and social achievements of the country and its population.

The study of a significant number of scientific, regulatory and practical materials allows us to argue that a clear definition and even representation of management in the tourism industry as the flagship of the national and regional development of the service sector has not yet fully developed in the scientific community, with all the interest and relevance of

\footnotetext{
*Corresponding author: matveeva_ai@usue.ru
} 
the problem. The concept of establishing the tourism service sector as a system of formed views on this area of the economy and the processes taking place in this area, with the development of market relations and the accumulation of scientific knowledge about its structure and prospects have significantly transformed.

The complexity, significance and relative novelty of the service sector in the tourism industry, as well as the lack of fundamental work in this area, have led to the emergence and use of many terms that define its essence. The most common were: the tourism sector, the economy of tourist services, the field of tourism services, the tourism industry, the service sector, the tourist services market, the service area, the economy of tourist services. Therefore, the study of the tourism industry and its management as one of the socially significant management and socio-economic spheres, during the development of the digital economy does not lose its relevance.

\section{Materials and Methods}

The industry (management-production-technological) component of tourism is associated with the representation of it as a special, specialized branch of the economy. The economic development of tourism is characterized by impressive data on the world economic market. Thus, according to the World Tourism Organization, the number of tourist arrivals by 2020 will be 1.6 billion people, the world tourism revenues in 2020 will increase to 2 trillion dollars $[1,132]$.

In the writings of Russian and foreign scientists, the "tourist industry" is considered without due reasoning and is characterized simultaneously by elements of industry infrastructure, management in the tourism industry, forms of tourism and even individual events organized in the process of serving tourists. This approach is objectionable because it confuses the terminology of tourism and does not improve the structure of the industry and the interaction of its components [2]. According to BCG, tourism's contribution to the global economy in 2018 amounted to $10.4 \%$ of GDP and about $30 \%$ of exports. "The forecast for 2029 is already $11.5 \%$ of the world's GDP. Every tenth workplace is in one way or another connected with the tourism industry, which also has a multiplier effect and contributes to the development of related industries. There are 53 such related industries in Russia, and the economic impact can be very high. Best practices show that the return on investment in tourism sales covers costs by an average of 27 times," concluded the company.Experts of BCG concluded that by 2025 Moscow can enter the top ten world cities-champions in terms of the rate of growth of tourist traffic. The contribution of tourism to Russia's GDP by 2025 may double, to the economy of The city of Moscow - up to $6-8 \%$, and the city's revenue can also double, to 1.5 trillion rubles [3].

The methodological basis of the article is the principles of integrity, synthesis and analysis.

The formation of the offer of tourist services requires taking into account external and internal factors, ignoring which leads to miscalculations in the work of management in the tourism industry. External factors act as unmanageable, uncontrollable. They are divided into macro-level factors (political, regulatory, scientific, technical, natural, demographic, cultural) and meso levels (consumers, competitors, media suppliers, corruption). Internal controlled - managed factors include those that managers of a travel company can manage, organize and control. Economic risks occupy a special place in their composition.

The tasks and actions of tourism organizations to create supply in the service market and achieve the desired economic results should be closely related to the peculiarities of consumer demand. Market researchers have been debating for years on the topic of Demand - gives birth to Supply or Supply - Demand, and at the same time all note their 
inseparable connection and interdependence. In this context, the demand for services is based on consumer motivation and competent management.

The effectiveness of the management of the tourism organization, which operates, requires, in addition to taking into account the motivations of tourist consumers, to study and take into account other factors that affect the behavioral characteristics of consumers of tourist services. Currently, the requirements for the formation of structure and approaches in the study of tourism market trends have changed significantly.

The strategic component of tourism in recent years has become increasingly important in modern scientific, normative publications and practical reports used the concepts of "strategy," "strategic management," "strategic objectives," "strategic development" etc. Analysis of interpretations of these concepts shows that the authors do not have a single opinion on the essence of the phenomenon. In the context of the subject matter, the publication should focus on the strategic component of tourism as an external service sector, and define the tourism strategy as a concrete long-term plan to achieve specific goals, and develop a strategy as finding goals and drawing up long-term plans.

Over the past ten years, the regional administration in Russia has been undergoing a clear transformation and a new approach to strategy development is being formed. The Strategic Management of Services and Tourism Development on the basis of the "International Cooperation and Export" which provides for a federal project "Export of Services"[4] is not optimal, as in this case it is only a matter of socio-economic development.

We emphasize that any author who analyzes the service sector in the tourism industry has the right to his own copyright vision of the definition of this scientific category. On this basis, we believe that the concept of "service in tourism" is legitimate in certain cases to replace the concept of "service in the tourism industry." At the same time, "service" is defined as the activity to provide service to the client. A service that satisfies the need of a customer.Paying tribute to the theoretical aspect of the study of the service sector in the tourism industry, it should be recognized that its real state and effectiveness of the impact on the management, economic and social situation of society is associated with the development of the service sector. Monitoring of their activities is based on the importance of exploring the problems and prospects of the production and technological aspect of the service sector.In modern statistics, the service sector in the industry is considered as a tertiary sector of the economy, a full part of production (agriculture - the primary sector of production, productivity - secondary).In a number of publications devoted to management in tourism, this approach is considered to be industry-specific and requires innovation. We consider it important to note that in practice and in theory - innovation is seen as a process of implementation of innovations, as a situation of successful development of social, economic, educational, service management and other areas. As the Russian tourism industry's market for services represents an innovative management and socio-economic platform with a regional character, new management and development technologies should be more actively developed and implemented in the most resource-appropriate territories.

\section{Results and Discussion}

Let's consider the problems of strategic development of the service sector and management in the tourism industry on the example of the servirization of the Sverdlovsk region. Servirization is most often used to define the strategic direction of the service sector and its individual industries. Progressive development of the service sector is defined as a model of the future socially oriented society, formed today at the federal and regional levels. In modern practice, the development of services in the regions is either "extensive or intensive" [4,41]. 
The emphasis of the region on the tourist product offered on the territory's service market is primarily due to the importance of tourism.

In the Sverdlovsk region and the regional center, this development of the tourism industry and its management is multifaceted and multidimensional. It includes strategic planning and management, research automation, marketing, organizational design of the service sector and each element of the service sector.

After studying the documents in more detail: The Sverdlovsk Region's Strategy for the Development of Domestic and Inbound Tourism until 2030, the Ministry of Economy and Territorial Development of the Sverdlovsk Region [6]; - On the approval of the concept of the Sverdlovsk Region's Domestic and Inbound Tourism Development Strategy for the period up to 2035 [7]; Order of the Ministry of Investment and Development of Sverdlovsk Region from 17.09.2018 [8]. We see that the regional government is supposed to form a strategy for the development of tourism based on the definition of the target model of the tourist market.

In the process of implementing the national project on international cooperation and export, the Sverdlovsk region (according to Rosstat) in 2018 took the 5th place among other regions of the country with a result of 343 million U.S. dollars. Data from the DAC Survey Analysis Center in 2018, conducted in 41 regions of Russia, showed that 57,966 foreign tourists were registered to live in the Sverdlovsk region, while the total number of foreign tourists in the region is only 5 percent, and the share of expenses from the implementation of services in the region also reaches only 5\%.Surveys of tourism workers show that the popularity of the Russian Federation and some of its regions as a tourist destination is increasing [10]. The above data describe a lack of governance and international tourism in the region. The same can be said, knowing that the influx of foreign tourists to the region, mainly, is carried out only from Germany, China and Ukraine, and more than three-quarters of the GDP generated by the industry is provided by domestic tourism. Thus, the development of the strategy for the development of the region's services sector should take into account not only the support and stimulation of certain industries, but above all the implementation of the innovative idea of structuring the regional complex, which offers an effective tourist product. An innovative approach is to develop a project orientation of the tourist product in the part intended for foreign tourists.

Sverdlovsk authorities have been declaring the need for active tourism development in the region for several years. Nevertheless, $80 \%$ of those who come to Sverdlovsk region are business tourists. Industry experts insist that a number of products have been developed in the region that may be of interest to both Russian and foreign tourists.

In the second most popular place is shopping. We have the largest shopping centers in Russia and residents of neighboring regions are guided by this. Some come for a specific brand.

In third place in winter - ski resorts, in summer - alloys and hikes. Ski centers have now started to carry out some work on errors and began to load their facilities even in the summer. For example, Mountain White makes various thematic hikes environmental routes, they have there anyone can pass the complex TRP. Today, the task is not only to create infrastructure for tourism, but also to load it regularly.

Despite the importance of the tourism industry in the country and regions, the statistical accounting in it at the moment is imperfect and to fully assess its impact on the economy is clearly insufficient. It is very difficult, in our view, to determine the impact of certain elements of the region's recreational potential on the structure, volume and effectiveness of the proposed tourist product, which allows it to be carried out in general and often with the help of not so much direct as indirect data. Objectively assessing the resources and capabilities of the Sverdlovsk region and Yekaterinburg as a tourist region, it should be noted their richness and diversity, which is necessary to determine the territory of tourist 
regions. The area is located in the northern part of the Ural Mountains and on the western part of the Siberian Plain. The area is $194,307 \mathrm{sq} \mathrm{km}$, with a population of 4.5 million (2018) [11].The climate in the Sverdlovsk region is continental, the presence of critical situations and natural anomalies, inevitable for tourists is almost non-existent. The region has great potential for medical and recreational tourism, active types of it. Features of the terrain stimulate the development of winter and summer sports, and the developed sports infrastructure of the region and its participation in the organization of international sporting events attracts sports fans. There are about 500 natural monuments on the territory, such as geological, geomorphological, hydrological, botanical and landscape, of interest not only for specialists, but also for young people.

The above data describe a lack of the management and organization of international tourism in the region. The same can be said, knowing that the influx of foreign tourists to the region, mainly, is carried out only from Germany, China and Ukraine, and more than three-quarters of the GDP generated by the industry is provided by domestic tourism. Thus, the development of a strategy for the development of the region's services sector should take into account not only the support and stimulation of certain industries, but above all the implementation of the innovative idea of structuring the regional complex, offering an effective tourist product.

\section{Conclusion}

The success of regional tourism requires the implementation of the activities of travel agencies precisely those areas and conditions that meet the requirements of tourists, are competitive in the Russian service market and contribute to the development of the entire service sector in the region. Some of these areas of tourism are already being implemented, but require the expansion of the list of their types, the revitalization of implementation and thoughtful integrated strategic development. Studying the experience of the most successful tourist areas abroad and in Russia revealed the importance of the following areas: ensuring the accessibility of tourism in the region; -creating an innovative space in the management of tourism; - building sustainable relationships with related service industries based on state-of-the-art technology; - simplification of interaction and integration of the environment and guest; - the development of a unique tourist product and the possibility of differentiating it; - improving the quality of services for tourists at all stages and in all places of visiting, etc.; - developing the tourist experience of visitors to the region and increasing the target audience. In the real practice of creating and promoting tourist regions, the problems of their strategic management are obvious. National service strategic development projects do not pay enough attention to the fact that the originality of each entity and its own objectives and how to achieve them are limited by the competence and functionality of regional bodies. Such a provision necessitates the expansion of the powers of the territorial authorities and changes in established regulations and established practices. The real implementation of the strategic development of the service sector and, in particular, tourism is possible only through concerted cooperation and integration of the interests of public organizations, scientific institutions and collectives, private companies, local forces and communities. This encourages and controls overall participation at various stages of sustainable tourism; to collect and disseminate information within the boundaries of the tourist area and to facilitate the efficient allocation of the necessary resources.

\section{References}

1. L.K. Ayushieva, Bulletin of the Buryat State University, 2 (2) (2015) 
2. T.A. Frolova, Tourism Industry, Tourism as an economic system (2011)

3. Research: the contribution of tourism to Russia's GDP by 2025 could double, https://ria.ru/

4. Passport of the national project (program) International cooperation and export (Approved by the Presidium of the Council under the President of the Russian Federation for Strategic Development and National Projects (Minutes of December 24, 2018 No. 16)), https://base.garant.ru/

5. O.V. Kryukova, D.V. Krumgolts, Bulletin of the Institute of Economics and Management, 3 (2010)

6. Strategy for the development of tourism in the Sverdlovsk region until 2030, http://economy.midural.ru/

7. On approval of the Concept of the Strategy for the development of domestic and inbound tourism in the Sverdlovsk region for the period up to 2035, Ministry of Investment and Development of the Sverdlovsk Region. Order of September 17, 2018 No. 194, http://docs.cntd.ru/

8. Order of the Ministry of Investment and Development of the Sverdlovsk Region No. 191, Publication No. 18679 dated September 18, 2018, http://www.pravo.gov66.ru/

9. Sverdlovsk Region was included in the Top 5 Exporters of Services Among Russian Regions, http://www.rusexporter.ru/

10. V.M. Matyunin, Topical issues of tourism development in Russia and regions, https://cyberleninka.ru/

11. Geography of the Sverdlovsk region, https: //geografia-sverd.ucoz.ru/ 